УДК $904: 67$ (477.72)-033.5

DOI: https://doi.org/10.33782/eminak2021.1(33).497

\title{
ВИРОБНИЦТВО СКЛА ЧИ ЙОГО ОБРОБКА? ЯГОРЛИЦЬКЕ ПОСЕЛЕННЯ У СВІТЛІ НОВИХ ДОСЛІДЖЕНЬ
}

\author{
Анжеліка Колесниченко ${ }^{1}$, Олег Ячук ${ }^{2}$ \\ ${ }^{1}$ Інститут археології НАН України (Київ, Україна) \\ e-mail: magtaban1984@gmail.com \\ ORCID: https://orcid.org/0000-0002-4598-5929 \\ 2 Департамент хімії Туринського університету (Турин, Італія) \\ e-mail: oleh.yatsuk@gmail.com \\ ORCID: https://orcid.org/0000-0002-9033-4199
}

\begin{abstract}
У статті висвітлено результати вивчення скляних намистин з Ягорлицького поселення та зразків піску довкола нього. У дослідженні використовувались методи природничих наук, а саме XRF, SEM-EDS та ICPMS. Хімічний склад намистин із золистого скла та піску свідчить про їх спорідненість за макроелементами та рідкісноземельними елементами. Отримані результати підтверджують гіпотезу А.С. Островерхова про місцеве виробництво скла.
\end{abstract}

Ключові слова: Ягорлиџька затока, Середземномор'я, архаїчна доба, намистина, хімічний аналіз, пісок, содове скло, золисте скло

Питання виробництва скла як сировини у добу заліза $є$ гостро дискусійним, адже, як вважається, до елліністичного періоду первинні майстерні невідомі у Середземноморському басейні ${ }^{1}$. У сучасній історіографії вчені більш критично розглядають докази первинного виробництва, або обробки скла. Наявність відходів склярства, таких як шлаки, тиглі, уламки стінок тиглів, або печей із залишками скла, фрагменти необробленого скла, або браковані вироби - не є доказами саме виробництва скла. Вони також можуть свідчити про різні технологічні маніпуляції з уже готовим склом. У пошуках відповіді на питання про центри первинного виготовлення скла, дослідники акцентують свою увагу на вивченні його хімічного складу та визначенні можливих джерел походження окремих складових сировини, наприклад, кобальту або соди (натрону) 2 . Проте, ці речовини, досить ймовірно, могли імпортуватися з різних джерел до однієї майстерні. Пісок, як основа скла, також привертав увагу вчених, а саме - їх цікавило вивчення його

\footnotetext{
${ }^{1}$ Henderson J. Ancient Glass: An Interdisciplinary Exploration. Cambridge: Cambridge University Press, 2013. 433 p.; Conte S., Arletti R., Henderson J., Degryse P., Blomme A. Different glassmaking technologies in the production of Iron Age black glass from Italy and Slovakia // Journal of Archaeological and Anthropological Sciences. 2016. Vol. 10. C. 503-521; Rehren Th., Freestone I. Ancient glass: from kaleidoscope to crystal ball // Journal of Archaeological Science. 2015. Vol. 56, P. 233-241.

2 Rehren Th. Aspects of the productions of cobalt-blue glass in Egypt // Archaeometry. 2001. № 43 (4). P. 483-489; Shortland A.J., Schachner L., Freestone I.C., Tite M. Natron as a flux in the early vitreous materials industry: sources, beginnings and reasons for decline // Journal of Archaeological Science. 2006. № 33. P. 521-530; Shortland A.J., Tite M.S., Ewart I. Ancient exploitation and use of cobalt alums from the Western Oases of Egypt // Archaeometry. 2006. № 48. P. 153-168; Devulder V., Degryse P. The Sources of Natron // Degryse P. (Ed.). Glass Making in the Greco-Roman World Results of the ARCHGLASS Project. Leuven: Leuven University Press, 2014. P. 87-95.
} 
ізотопного складуз . Наприклад, вивчення ізотопів стронцію у готових виробах Родосу, у порівнянні зі зразками піску, так само не дало вагомих результатів щодо підтвердження місцевого виробництва скла, оскільки ареал поширення відповідних пісків охоплює усе сирійсько-палестинське узбережжя4. Вказані дослідження проводилися винятково у межах Середземноморського басейну та Середнього Сходу. Дотепер дані з Чорноморського регіону не розглядалися. Саме тому Ягорлицьке поселення відкриває новий напрямок у пошуках первинних майстерень з виробництва скла.

Ягорлицьке поселення архаїчної доби (перша половина VI ст. до н.е.) 5 розміщується на узбережжі Ягорлицької затоки у Херсонській області в 4 км на північний захід від с. Іванівка Голопристанського району (рис. 1). У 1960-х - 1970-х роках поселення було сильно пошкоджено плантажною оранкою та лісонасадженнями. Поверхня на пам'ятці та навкруги неї вкрита піщаними дюнами. Тут розміщуються два солоних озера, а також одне безпосередньо на площі пам'ятки, розділяючи поселення на дві частини. На відміну від сучасного природного середовища, в архаїчну добу, ймовірно, поселення лежало біля рукава Дніпра, який тоді впадав у Чорне море через сучасну Ягорлицьку затокуб. Вірогідним $є$ припущення, за яким ця місцевість була частиною легендарної Гілеї7, описаної Геродотом (Herodotus, IV, 19, 54, 55). Таким чином, ремісники мали базові ресурси, які були необхідними для виробництва скла.

Науковими пошуками А.С. Островерхова й інших дослідників було доведено існування тут розвинутого ремісничого центру. А.С. Островерховим були вивчені залишки печей з виготовлення й обробки заліза та знахідки бронзових виробів,

\footnotetext{
${ }^{3}$ Henderson J., Evans J., Nikita K. Isotopic evidence for the production, provenance and trade of Late Bronze Age glass in the Mediterranean // Journal of Mediterranean Archaeology and Archaeometry. 2010. № 10 (1). P. 1-25; Brems D., Ganio M., Degryse P. The Sr-Nd isotopic fingerprint of sand raw materials // Degryse P. (Ed.). Glass Making in the Greco-Roman World Results of the ARCHGLASS Project. Leuven: Leuven University Press, 2014. P. 51-67.

4 Blomme A., Elsen J., Brems D., Shortland A.J., Dotsika E., Degryse P. Tracing the primary production location of core-formed glass vessels, Mediterranean Group I. // Journal of Archaeological Science: Reports. 2016. № 5. P. 8.

5 Датування поселення залишається дискусійним питанням. В.В. Рубан на основі амфорного матеріалу, висловив думку, що поселення було засновано близько 630 р. до н.е. Н.А. Гаврилюк та А.С. Островерхов припускали, що поселення існувало з кінця VII ст. до н.е. до V ст. до н.е. Хоча А.С. Островерхов повертаючись до вивчення матеріалу схилявся до думки, що поселення могло датуватися в межах кінця VII - першої половини VI ст. до н.е. або VI - початку V ст. до н.е. Останні дослідження з вивчення розписної кераміки А.В. Буйських і С.Б. Буйських свідчать, що поселення виникло у першій чверті VI ст. до н.е. і проіснувало до середини століття. Див.: Рубан В.В. Керамика Ягорлыцкого поселения из собрания Херсонского музея // Советская археология. 1983. № 1. С. 285-291; Гаврилюк Н.А., Островерхов А.С. Керамический комплекс Ягорлыцкого поселения // Археологические исследования на Украине в 1976-1977 гг. Тез. конф. ИА АН УССР. Ужгород, 1978. С. 63-64; Буйских С.Б., Буйских А.В. К хронологии архаических поселений хоры Ольвии Понтийской // Боспорские исследования. 2010. Вып. XXIV. С. 26; Островерхов А.С. Антична склоробна майстерня на Ягорлицькому поселенні // Археологія. 1978. № 25. С. 41; Островерхов А.С. Древнейшее античное производство стеклянных бус в Северном Причерноморье // Советская археология. 1981. № 4. С. 214.

6 Шилик К.К. К палеографии Ольвии // Крыжицкий С.Д., Бибиков С.Н., Козуб Ю.И. (ред.). Ольвия. Киев: Наукова думка, 1975. С. 84-85; Агбунов М.В. Загадки Понта Эвксинского. Москва: Мысль, 1985. С. 120-121; Ивлеев М.М. Очерки античной палеоэкологии Нижнего Побужья и Нижнего Поднепровья. Киев: Олег Филюк, 2014. С. 68-70, рис. 19.

7 Ивлеев М.М. Очерки античной палеоэкологии... С. 88-90, 93, рис. 22.
} 
або бронзових відходів, які свідчать про обробку бронзив. Свідоцтвом склярства $\epsilon$ зібрані фрагменти кераміки із залишками скла, багато шлаків, уламки тиглів із застиглою скляною масою, різноманітні відходи з обробки скла у вигляді крапель, ниток, шматочків скла та численні цілі або фрагментовані намистиния. На основі вказаних артефактів і вивчення хімічного складу скла намистин А.С. Островерхов припустив, що на пам'ятці виготовлялося власне скло й оброблялося скло, що було імпортоване у злитках ${ }^{10}$. Автор підкреслював, що сода, як домішка у процесі варіння скла, могла як привозитись, так і бути місцевого походження 11 . Проте, існування первинної (склоробної) майстерні на Ягорлицькому поселенні залишалося гіпотезою, яка дотепер не розроблялася.

\section{Хімічний склад скла намистин за «старими» даними.}

Розглядаючи дані А.С. Островерхова та В.О. Галібіна ${ }^{12}$ на тлі масиву сучасних хімічних аналізів античного скла, можна стверджувати, що ягорлицькі намистини вироблялися з трьох типів скла: «содового» (звареного на основі соди, анг. low magnesia glass, LMLK), «золистого» (звареного на основі золи, анг. high magnesia glass, HMHК) та скла з проміжними характеристиками, які не знаходять прямих аналогій і можуть свідчити про подовжений процес переробки содового скла, умовно скло «третього типу»13.

3 содового скла виготовлені усі біконічні намистини, деякі округлі й іноді окремі елементи намистин з очками. Хімічний склад скла характеризується низьким вмістом оксиду калію (нижче 2\%), який було майже неможливо встановити обладнанням, застосованим В.О. Галібіним. Фактичний рівень $\mathrm{K}_{2} \mathrm{O}$ може становити не більше 0,5\%, про що свідчить «мокрий» хімічний аналіз округлої бірюзової намистини, проведений С. Джалаловою14. Низький вміст калію - близько 0,13\% зафіксований у дуже схожих за морфологією біконічних намистинах з пам'ятки Модлніца (Польща) ${ }^{15}$. Вміст магнію в ягорлицьких содових намистинах так само незначний (MgO - 0,6 до 0,8\%, сер. арифм. 0,7\%) (рис. 2). Содове скло ягорлицьких намистин має незначну домішку глинозему $\left(\mathrm{Al}_{2} \mathrm{O}_{3}-0,45-0,9 \%\right.$, сер. 0,6\% (рис. 2)), окрім бочкоподібної намистини (№ $18, \mathrm{Al}_{2} \mathrm{O}_{3}-3 \%$ ), яка $є$ винятком і у

\footnotetext{
8 Островерхов А.С. Про чорну металургію на Ягорлицькому поселенні // Археологія. 1978. № 28. C. 26-35.

${ }_{9}^{9}$ Островерхов А.С. Антична склоробна майстерня... С. 42 , рис. $1,2$.

10 Островерхов А.С. Технология античного стеклоделия: архаика (по археологическим материалам Северного Причерноморья). Киев: АН Украины, 1993. С. 5-6, 36.

11 Островерхов А.С. Древнейшее античное производство стеклянных бус... С. 225.

12 Роботами аналітика В.О. Галібіна було отримано дані хімічного складу 65 зразків скляних намистин, шлаків і шматочків необробленого скла з Ягорлицького поселення. Вивчення артефактів проводилося методом кількісного спектрального аналізу в лабораторії Інституту історії матеріальної культури (Санкт-Петербург). Дані опубліковані у роботі: Островерхов А.С. Технология античного стеклоделия: архаика (по археологическим материалам Северного Причерноморья). Киев: АН Украины, 1993.

13 Kolesnychenko A.M. Yahorlyk workshop, core-formed vessels and «natron glass revolution» in North Pontic region // Acta Archaeologica Lodziensia. 2018. № 64. P. 50.

14 Островерхов А.С. Технология античного стеклоделия: архаика... Табл. 2, № 4.

15 Purowski T., Nowak A., Wagner B., Bulska E. Badania składu chemicznego szkła paciorków z cmentarzyska z wczesnej epoki żelaza w Modlnicy // Dzięgielewski K., Dzięgielewska M., Sztyber A. Via Archaeologic «Źródła z badań wykopaliskowych na trasie autostrady A4 w Małopolsce». Modlnica, stan. 5. Od późnej epoki brązu po czasy średniowiecza. Kraków: Krakowski Zespół do Badań Autostrad s.j. S. 239-254, Tab. 2.
} 
типологічному розмаїтті Ягорлицької майстерні. Оксид заліза у склі намистин не перевищує $1 \%\left(\mathrm{Fe}_{2} \mathrm{O}_{3}-0,4-0,9 \%\right)$ у випадках, коли оксид заліза не $є$ барвником, як, наприклад, у склі майже чорної намистини з очками, де $\mathrm{Fe}_{2} \mathrm{O}_{3}$ складає 7\%16. Рівень глинозему та заліза свідчить, що для виробництва содового скла використовувалося дуже чисте джерело кремнезему. Содове скло містить також $\mathrm{Na}_{2} \mathrm{O}$ (8$22 \%$, сер. 16,9\%), СaO (9-15\%, сер. 12\%).

Ягорлицькі скляні намистини зі скла, звареного на основі попелу рослин, займають особливе місце на графіку $\mathrm{K}_{2} \mathrm{O} / \mathrm{MgO}$, якщо їх порівнювати з іншими випадками золистого скла раннього залізного віку з Європи та Близького Сходу. Ягорлицьке скло характеризується приблизно однаковою кількістю калію та магнію ( $\mathrm{K}_{2} \mathrm{O}$ 3-6\%, cep. 4.2\%; MgO 2,5-7\%, сер. 3,6\%), і тому, точки на графіку формують однорідне скупчення ${ }^{17}$. Високі відсотки калію та магнію наближають скло Ягорлика до групи месопотамських зразків доби пізньої бронзи, відомих, у тому числі, і з кількох пам'яток в Європі, як і до скла раннього залізного віку з Пелли (Йорданія) ${ }^{18}$. Однак, у випадку Ягорлика, саме калію більше, ніж магнію, а не навпаки, як у зразках з Месопотамії, Родосу та Італії. Золисте скло намистин з Ягорлицького поселення багате на алюміній і залізо $\left(\mathrm{Al}_{2} \mathrm{O}_{3}-1,9-10 \%\right.$, сер. 4,4\%; $\mathrm{Fe}_{2} \mathrm{O}_{3}-0,8-5 \%$, сер. 2,7\%). Іноді, кількість оксиду заліза достатньо велика, щоб припускати навмисну домішку компонентів, багатих на цей елемент. Переважно, це саме чорне скло - основа намистини з очками. Оксид заліза у низьких відсотках присутній у двох бірюзових намистинах, забарвлених оксидом міді (CuO - 3,5-4\%). Скло зварене на основі рослинного попелу, зазвичай, мало досить високий вміст глинозему $\left(\mathrm{Al}_{2} \mathrm{O}_{3}-1,9-10 \%\right.$, сер. 4,4\%). Такі показники вмісту глинозему чітко відрізняються від показників у склі ягорлицьких намистин, яке зварено на основі соди. Беручи до уваги, що глинозем, в основному, входив до складу стародавнього скла як домішка піску, який використовували для варіння, обгрунтовано припускати, що содове та золисте скло Ягорлика виготовлялися з різної сировини й, отже, ймовірно, у різних центрах виробництва.

Хімічний склад ягорлицького скла, звареного на основі золи, достатньо оригінальний на тлі зразків доби пізньої бронзи та раннього заліза, аби припускати його незалежне виробництво. На жаль, аналізи хімічного складу скла 1970-1980х років мають значні за діапазоном лабораторні похибки і не містять даних за розсіяними елементами, які у сучасній науці є важливими для вивчення саме сировини для виготовлення скла.

\section{Нові дані вивчення скляних намистин та піску.}

У 2018-2020 рр. було проведено повторне обстеження пам'ятки та зібрано зразки піску для вивчення його хімічного складу і порівняння отриманих даних 3 хімічним складом намистин та уламками скла ${ }^{19}$. Хімічний склад намистин у за-

\footnotetext{
16 Островерхов А.С. Технология античного стеклоделия: архаика... Табл. 2, № 39.

17 Kolesnychenko A.M. Yahorlyk workshop... P. 49-51, fig. 2, 6.

18 Varberg J., Gratuze B., Kaul F., Hansen A.H., Rotea M., Wittenberger M. Mesopotamian glass from Late Bronze Age Egypt, Romania, Germany,and Denmark // Journal of Archaeological Science. 2016. № 74. P. 184-194; Reade W., Freestone I.C., Bourke S. Innovation and continuity in Bronze and Iron Age glass from Pella Jordan // Annales of the 17e Congrès de l'Association Internationale pour l'Histoire du Verre. 2009. P. 48, fig. 1.

19 Результати вивчення зразків піску та скляних намистин з повним переліком лабораторних аналізів готуються до публікації спільно з співавторами О.Яцуком, Ж. Мірао, М. Кошта,
} 
гальних рисах відповідає «старим» результатам А.С. Островерхова. Так само, встановлено використання ягорлицькими ремісниками двох типів скла - содового та золистого, а також «третього типу» скла, який свідчить про незакінчений (на певному етапі) процес варіння скла на основі золи або про подовжену його переробку (зразок Үа-8).

У районі поселення наявні різні типи відкладів піску: є сучасні еолові, древні еолові, алювіальні, лиманні та морські (пляжні). В ході дослідження були відібрані зразки піску з різних точок навкруги поселення у радіусі 16 км. Хімічний склад намистин із содового скла погано корелює з піском, добраним навкруги поселення - всі піски мають вищий рівень оксиду алюмінію, ніж містилось у намистинах содового скла (рис. 2) 20 . Два зразки місцевого піску мають хімічний склад, який найбільш когерентний хімічному складу скляних намистин з очками, скло останніх зварено на основі золи. Перше місце відбору (зразок Qua) знаходиться у кар'єрі «Шабівський» між селами Виноградне та Геройське на березі Дніпровської затоки, другий пункт (зразок IV-s) зафіксовано на південь від с. Іванівка у місці впадіння одного із старих рукавів Дніпра в Ягорлицьку затоку.

На відміну від еолового та пляжного піску ці два зразки піску складаються з більш дрібних піщинок і відрізняються меншою концентрацією кремнезему. Вони насичені глиноземом та оксидом заліза. Пісок з кар'єру має вміст глинозему $\left(\mathrm{Al}_{2} \mathrm{O}_{3}\right) 4,4 \%$, та оксиду заліза $\left(\mathrm{Fe}_{2} \mathrm{O}_{3}\right)$ 0,6\%, пісок на південь від с. Іванівка має показники $\mathrm{Al}_{2} \mathrm{O}_{3} 10,1 \%$, та оксиду заліза $\left(\mathrm{Fe}_{2} \mathrm{O}_{3}\right) 3,6 \%$. Пісок з другого пункту має більше «домішок». Обидва зразки за процентним співвідношенням вмісту цирконію добре корелюють із золистими намистинами. Проте ці показники не є остаточними доказами використання місцевого піску у скловарінні, адже вміст основних елементів може відповідати і піскам з інших депозитів, а скло, як напівфабрикат, могло перевозитись на великі відстані. Найбільш достовірними $є$ результати аналізів ICP-MS зразків піску щодо вмісту рідкісноземельних елементів.

Порівняння відповідних профілів вмісту рідкісноземельних елементів (нормалізованих за хондритами) ${ }^{21}$ намистин і зразків піску вказують, що виділені за складом макроелементів (див. вище) три хімічних типи скла відрізняються і за профілями рідкісноземельних елементів. Так, уламки необробленого скла (зраз-

П. Барулаш. Хімічні аналізи проводилися за допомогою XRF, SEM-EDS та ICPMS у лабораторії Hercules в Еворі (Португалія). Зразки скляних намистин і напівфабрикатів (загальним числом 23) позначались індексом Үа з наступним числовим означенням (наприклад, Үа-1).

20 У загальному випадку порівняння вмісту окремих елементів у склі та сировині для його виготовлення некоректне. Але стосовно алюмінію та рідкісноземельних елементів маємо підстави припускати, що у даному конкретному випадку таке порівняння можливе, оскільки основним джерелом їх надходження у скло виступав пісок. Хоча алюміній міг потрапляти у скло разом 3 золою (Галибин В.А. Состав стекла как археологический источник. Санкт-Петербург: Петербургское Востоковедение, 2001. С. 26-27). Відносна частка $\mathrm{Al}_{2} \mathrm{O}_{3}$ істотно не зменшувалась під час варіння, у випадку відсутності значних домішок склоутворювальних компонентів (наприклад, свинцю). Такі випадки не зафіксовані у проаналізованому переліку намистин. Тому скло намистин з низьким вмістом алюмінію не могло бути зварене на основі піску зі значною його домішкою.

${ }^{21}$ Нормалізацію здійснено за W. McDonough i S. Sun - основа логарифму. При побудові порівняльного графіку були враховані найтиповіші намистини (4 екз.), які представляють аналогічні результати аналізів за рештою зразків (33 од.). Див: McDonough W.F., Sun S.S. The composition of the Earth // Chemical Geology. 1995. Vol. 67 (5). P. 1050-1056; Шарпенюк Л.Н. (ред.) Практическая петрология: методические рекомендации по изучению магматических образований применительно к задачам госгеолкарт. Санкт-Петербург: Изд-во ВСЕГЕИ, 2017. С. 102-104, табл. 2. 
ки Үа-7, 8, 17) мають найвищу концентрацію рідкісноземельних елементів та $€$ близьким за цими показниками до зразку піску, відібраного на південь від c. Іванівка (зразок Iv-s). Вони формують групу 1 (рис. 3).

Вироби із содового скла (біконічні намистин, зразки Үа-18, 19, 20, 23) групується разом за малою кількістю рідкісноземельних елементів у цілому, особливо за елементами La, Ce, Sm, Eu. Частина біконічних намистин (Ya-20, 23) виконана зі скла з високим вмістом тяжких рідкісноземельних елементів (група 2, рис. 3) на відміну від групи 4 (Үа-18, 19, рис. 3). Тому, можемо припускати, щонайменше, два джерела сировини для виготовлення содового скла. Можливо, ці відклади піску локалізувались в одному регіоні, про що свідчить ідентичність зразків груп 2 і 4 за легкими рідкісноземельними елементами. Жоден із проаналізованих зразків піску з околиць Ягорлицького поселення не відповідає їм за вмістом вищезгаданих елементів. Найбільш схожими до ягорлицьких содових намистин, за складом основних і рідкісноземельних елементів, $є$ намистини VIIV ст. до н.е. з Метоні (Піерія, Греція) ${ }^{22}$. Візуальне спостереження за графіком показують значну схожість ягорлицьких зразків Үа-18, 19 зі зразками з Метоні (рис. 4). Намистини Үа-20, 23 так само дещо відрізняються за складом, що може пояснюватися різним джерелом піску або недостатньою порівняльною вибіркою.

Нарешті, золисте скло (група 3 - ягорлицькі намистин з очками, зразки Үа-3, $12,13 a, 13 b)$ має середній вміст рідкісноземельних елементів і добре відповідає графіку нормалізованих відсотків цих елементів для зразку піску з кар'єру між селами Виноградне та Геройське (зразок Qua) (рис. 3). За рідкісноземельними елементами близьким до хімічного складу золистих намистин є також зразок піску Iv-s (відібраний на південь від с. Іванівка). Проте, вміст алюмінію у зразку піску Iv-s занадто високий $\left(\mathrm{Al}_{2} \mathrm{O}_{3}-10,1 \%\right)^{23}$ у порівнянні з готовим склом з Ягорлицького поселення (зразки Үа-7, 8, 17 мають вміст $\mathrm{Al}_{2} \mathrm{O}_{3}-3,4-5,8 \%$ ). Тому, на даному етапі дослідження, найбільш ймовірним джерелом сировини для них виступає зразок піску Quа. Хоча не виключено, що намистини з високим вмістом глинозему (8-10\%), які були проаналізовані А.С. Островерховим і В.О.Галібіним (№ 20a, 25 a), але відсутні у вибірці для нових аналізів, виготовлялися саме з піску, взятого на південь від с. Іванівка.

На порівняльному графіку вмісту рідкісноземельних елементів пісків і готового скла окремо виділяються зразок піску Ryb-Q і блакитна намистина Ya-10. Намистина також вирізняється середнім між золистим і содовим вмістом алюмінію $\left(\mathrm{Al}_{2} \mathrm{O}_{3}-1,5 \%\right)$, який не відповідає зразку піску Ryb-Q $\left(\mathrm{Al}_{2} \mathrm{O}_{3}-4 \%\right)$. У зазначених зразках фіксуються розбіжності La, Ce (рис. 3). Лише як гіпотезу, можна припустити, що зразок Үа-10 відображає переробку скла (можливо у тиглях після виготовлення золистого скла) з додаванням імпортної содової фрити. Всі інші зразки піску (Iv-Q, Ya-B, For, Ya-S, Vyn-S, Ryb-L) мають занизький вміст рідкісноземельних елементів, який не відповідає скляним намистинам з Ягорлицького поселення.

Таким чином, можна впевнено стверджувати, що золисте скло на поселенні вироблялося з місцевої сировини. У процесі варіння скла міг використовуватись пі-

\footnotetext{
22 Blomme A., Degryse P., Dotsika E., Ignatiadou D., Longinelli A., Silvestri A. Provenance of polychrome and colourless 8the4th century BC glass from Pieria, Greece: A chemical and isotopic approach // Journal of Archaeological Science. 2017. Vol. 78. P. 134-146.

23 Високий вміст глинозему може пояснюватись періодичним затопленням місцевості, у результаті чого міг збільшуватись вміст глини та мулу у піску.
} 
сок з відкладів типу Qua, взятого між селами Виноградне та Геройське. Ймовірно, ремісники ягорлицьких майстерень експериментували у пошуках сировини і могли використовувати інші поклади місцевого скла, як, наприклад, зразок Iv-S, взятий на півдні від с. Іванівка. Натомість, содове скло не знаходить відповідників у місцевих зразках піску та, скоріш за все, імпортувалося до Нижнього Подніпров'я. Майстри Ягорлицького поселення не тільки виготовляли намистини з уже готового імпортованого скла, а й продукували певну кількість скла з місцевої сировини 24. Різні методи обробки скла з вільним використанням різних традицій простежуються як у техніці формування намистини з золистого та содового скла, так і у свідоцтвах переробки скла, які простежені за хімічним складом окремих зразків.

Сучасний хімічний аналіз підтверджує гіпотезу А.С. Островерхова про місцеве скловаріння на Ягорлицькому поселенні. На тлі практично повної відсутності первинних майстерень з виготовлення скла як сировини у Середземномор'ї доеліністичного часу, цей факт робить Ягорлицьке поселення ключовим джерелом для вивчення античного склярства.

\section{REFERENCES}

Agbunov, M.V. (1985). Zagadki Ponta Evksinskogo [Mysteries of Pontus Euxinus]. Moskva: Mysl [in Russian].

Buiskikh, S.B. \& Buiskikh, A.V. (2010). K khronologii arkhaicheskikh poselenii khory Olvii Pontiiskoi [On the chronology of the archaic settlements of the chora of Pontic Olbia]. Bosporskie issledovaniia, XXIV, 3-37 [in Russian].

Blomme, A., Elsen, J., Brems, D., Shortland, A.J., Dotsika, E. \& Degryse, P. (2016). Tracing the primary production location of core-formed glass vessels, Mediterranean Group I. Journal of Archaeological Science: Reports, 5, 1-9

Blomme, A., Degryse, P., Dotsika, E., Ignatiadou, D., Longinelli, A. \& Silvestri, A. (2017). Provenance of polychrome and colourless $8^{\text {th }} 4^{\text {th }}$ century BC glass from Pieria, Greece: A chemical and isotopic approach. Journal of Archaeological Science, 78, 134-146.

Brems, D., Ganio, M. \& Degryse, P. (2014). The Sr-Nd isotopic fingerprint of sand raw materials. In Degryse, P. (Ed.). Glass Making in the Greco-Roman World Results of the ARCHGLASS Project. Leuven: Leuven University Press, 51-67.

Conte, S., Arletti, R., Henderson, J., Degryse, P. \& Blomme, A. (2016). Different glassmaking technologies in the production of Iron Age black glass from Italy and Slovakia. Journal of Archaeological and Anthropological Sciences, 10, 503-521.

Devulder, V. \& Degryse, P. (2014). The Sources of Natron. In Degryse, P. (Ed.). Glass Making in the Greco-Roman World Results of the ARCHGLASS Project. Leuven: Leuven University Press, 87-95.

Gavriliuk, N.A. \& Ostroverkhov, A.S. (1978). Keramicheskii kompleks Yagorlytskogo poseleniia [Ceramic complex of the Yahorlyk settlement]. Tezisy dokladov XVII Konferentsii Instituta arkheologii AN USSR. Uzhgorod, aprel 1978 goda, pp. 63-64 [in Russian].

Galibin, V.A. (2001). Sostav stekla kak arkheologicheskii istochnik [Glass composition as an archaeological source]. Sankt-Petersburg: Peterburgskoe Vostokovedenie [in Russian].

Henderson, J. (2013). Ancient Glass: An Interdisciplinary Exploration. Cambridge: Cambridge University Press.

Henderson, J. Evans, J. \& Nikita, K. (2010). Isotopic evidence for the production, provenance and trade of Late Bronze Age glass in the Mediterranean. Journal of Mediterranean Archaeology and Archaeometry, 10 (1), 1-25.

Ivleev, M.M. (2014). Ocherki antichnoi paleoekologii Nizhnego Pobuzhia i Nizhnego Podneprovia [Essays on the ancient paleoecology of the Lower Bug and the Lower Dnieper]. Kiev: Oleg Filiuk [in Russian].

Kolesnychenko, A.M. (2018). Yahorlyk workshop, core-formed vessels and «natron glass revolution» in North Pontic region. Acta Archaeologica Lodziensia, 64, 45-57.

McDonough, W.F, \& Sun, S.-s. (1995). The composition of the Earth. Chemical Geology, 67 (5), 1050-1056.

\footnotetext{
24 У процентному співвідношенні з вибірки у 800 екземплярів намистини розподіляються: 81\% біконічні, $12 \%$ - округлі, $9 \%$ - намистини з очками.
} 
Ostroverkhov, A.S. (1978). Antychna sklorobna maisternia na Yahorlytskomu poselenni [Ancient glass workshop on the Yahorlyk settlement]. Arkheolohiia, 25, 41-49 [in Ukrainian].

Ostroverkhov, A.S. (1981). Drevneishee antichnoe proizvodstvo stekliannykh bus v Severnom Prichernomorie [The oldest ancient production of glass beads in the Northern Black Sea region]. Sovetskaia arkheologiia, 4, 214-228 [in Russian].

Ostroverkhov, A.S. (1978). Pro chornu metalurhiiu na Yahorlytskomu poselenni [On the iron metallurgy at the Yahorlyk Settlement]. Arkheolohiia, 28, 26-35[in Ukrainian].

Ostroverkhov, A.S. (1993). Tekhnologiia antichnogo steklodeliia: arkhaika (po arkheologicheskim materialam Severnogo Prichernomoria) [Ancient glass-making technology: Archaic (based on archaeological materials from the Northern Black Sea Region)]. Kiev: AS Ukraine [in Russian].

Purowski, T., Nowak, A., Wagner, B. \& Bulska, E. (2015). Badania składu chemicznego szkła paciorków z cmentarzyska z wczesnej epoki żelaza w Modlnicy. In Dzięgielewski, K., Dzięgielewska, M. \& Sztyber, A. (Eds.). Via Archaeologic «Źródła z badań wykopaliskowych na trasie autostrady A4 w Małopolsce». Modlnica, stan. 5. Od późnej epoki brązu po czasy średniowiecza Kraków: Krakowski Zespół do Badań Autostrad s.j., 239-254 [in Polish].

Reade, W., Freestone, I.C. \& Bourke, S. (2009). Innovation and continuity in Bronze and Iron Age glass from Pella Jordan. Annales of the 17e Congrès de l'Association Internationale pour l'Histoire du Verre, 47-54.

Rehren, Th. (2001). Aspects of the productions of cobalt-blue glass in Egypt. Archaeometry, 43 (4), 483489.

Rehren, Th. \& Freestone, I. (2015). Ancient glass: from kaleidoscope to crystal ball. Journal of Archaeological Science, 56, 233-241.

Ruban, V.V. (1983). Keramika Yagorlytskogo poseleniia iz sobraniia Khersonskogo muzeia [Ceramic of the Yahorlyk settlement from the collection of the Kherson Museum]. Sovetskaia arkheologiia, 1, 285291 [in Russian].

Sharpeniuk, L.N. (red.) (2017). Prakticheskaia petrologiia metodicheskie rekomendatsii po izucheniiu magmaticheskikh obrazovanii primenitelno $k$ zadacham gosgeolkart [Practical petrology: guidelines for the study of magmatic formations in relation to the tasks of state geological maps]. SanktPetersburg [in Russian].

Shilik, K.K. (1975). K paleografii Olvii [Towards the paleography of Olbia]. In Kryzhitskii, S.D., Bibikov, S.N. \& Kozub, I.Yu. (Eds). Olviia. Kiev: Naukova dumka, 51-91[in Russian].

Shortland, A.J., Schachner, L., Freestone, I.C. \& Tite, M. (2006). Natron as a flux in the early vitreous materials industry: sources, beginnings and reasons for decline. Journal of Archaeological Science, 33, 521-530.

Shortland, A.J., Tite, M.S. \& Ewart, I. (2006). Ancient exploitation and use of cobalt alums from the Western Oases of Egypt. Archaeometry, 48, 153-168.

Varberg, J., Gratuze, B., Kaul, F., Hansen, A.H., Rotea, M. \& Wittenberger, M. (2016). Mesopotamian glass from Late Bronze Age Egypt, Romania, Germany,and Denmark. Journal of Archaeological Science, 74, 184-194.

\section{Anzhelika Kolesnychenko}

(Institute of Archaeology National Academy of Sciences of Ukraine, Kyiv, Ukraine)

e-mail: magtaban1984@gmail.com

ORCID: https://orcid.org/0000-0002-4598-5929

\section{Oleh Yatsuk}

(The University of Turin. Department of chemistry, Turin, Italy)

e-mail: oleh.yatsuk@gmail.com

ORCID: https://orcid.org/0000-0002-9033-4199

\section{Glass-making or glass-working? Yahorlyk settlement in the light of recent research}

Due to the absence of direct data on glass-making facilities in the Mediterranean Europe prior to the Hellenistic period, the Yahorlyk workshop (VI century BC) gains a particular importance. The workshop is situated along the coast of Yahorlyk bay, a shallow and long 
body of water in the Southern Ukraine, Kherson region. It was investigated on numerous occasions since 1972 and yielded abundant evidence of iron-production and bronze-working. The glass objects (remains of vitreous by-products, broken and complete beads etc.) are also common. Over 60 samples of glass were analyzed by A.S. Ostroverkhov and V.A. Galibin in 1980-ies. These results eneabled A.S. Ostroverkhov to put forward a hypothesis of local glass production at the Yahorlyk site. This paper tests this hypothesis on the basis of re-analysis of old dataset and a small series of samples treated by modern, enhanced methods of chemical analysis XRF, SEM-EDS and ICPMS in Hercules laboratory at Evora (Portugal).

The old dataset, when revisited, revealed evidence of three types of glass that were worked by Yahorlyk craftsmen: low magnesia, high magnesia and a particular «third» type, which characteristic for glass pieces of undefined shape. These types are not only different by ratio of potassium and magnesium but also have a variable chemical composition in general. Namely, the percentage of alumina varies greatly: it are almost absent in low magnesia glass and relatively high in high magnesia glass. It is low in the objects of the «third» type as well, making this chemical type similar to low magnesia glass.

The samples of sands were selected at different outcrops around the settlement and the content of rare earth elements (REE) was studied. Several samples were rejected as possible sources of sand for glass production. However, two samples (Qua and Iv-s) demonstrate significant similarities with REE composition in glass beads from Yahorlyk site.

Low magnesia glass beads (biconical beads) form two distinct groups on the graph of REE. Thus, at least two different types of sands were employed in their production. None of the local sand samples resembles chemical composition of biconical beads. Low magnesia glass was imported from elsewhere and the beads were produced from that material on the site.

High magnesia glass beads (mostly eye-beads) appear to correlate in the REE graphs of two sand samples Qua (sand from a quarry on the southern coast of Dnieper bay) and Iv-s (sand from the plane where one of the Dnieper presently non-existent branches entered Yahorlyk bay). The latter has too high content of alumina to be a source of sand for the beads analyzed recently. However, there were several beads with equally high alumina content in the old dataset. The former sediment sample (Qua) corresponds the REE composition of high magnesia beads from the Yahorlyk site and can be a source of raw material for their production. High magnesia glass could be produced at the Yahorlyk workhop and later worked into eye beads there.

Thus, new analyses proved an old hypothesis of A.S. Ostroverkhov about local glassmaking at the Yahorlyk workshop. This fact makes the site of Yahorlyk a crucial archaeological source for research on Archaic glass-working in the Pontic Region as well as in the ancient Greece and Mediterranean basin in general.

Keywords: Yahorlyk Bay, Mediterranean, Archaic period, beads, chemical analysis, sand, natron-based glass, plant-ash glass 


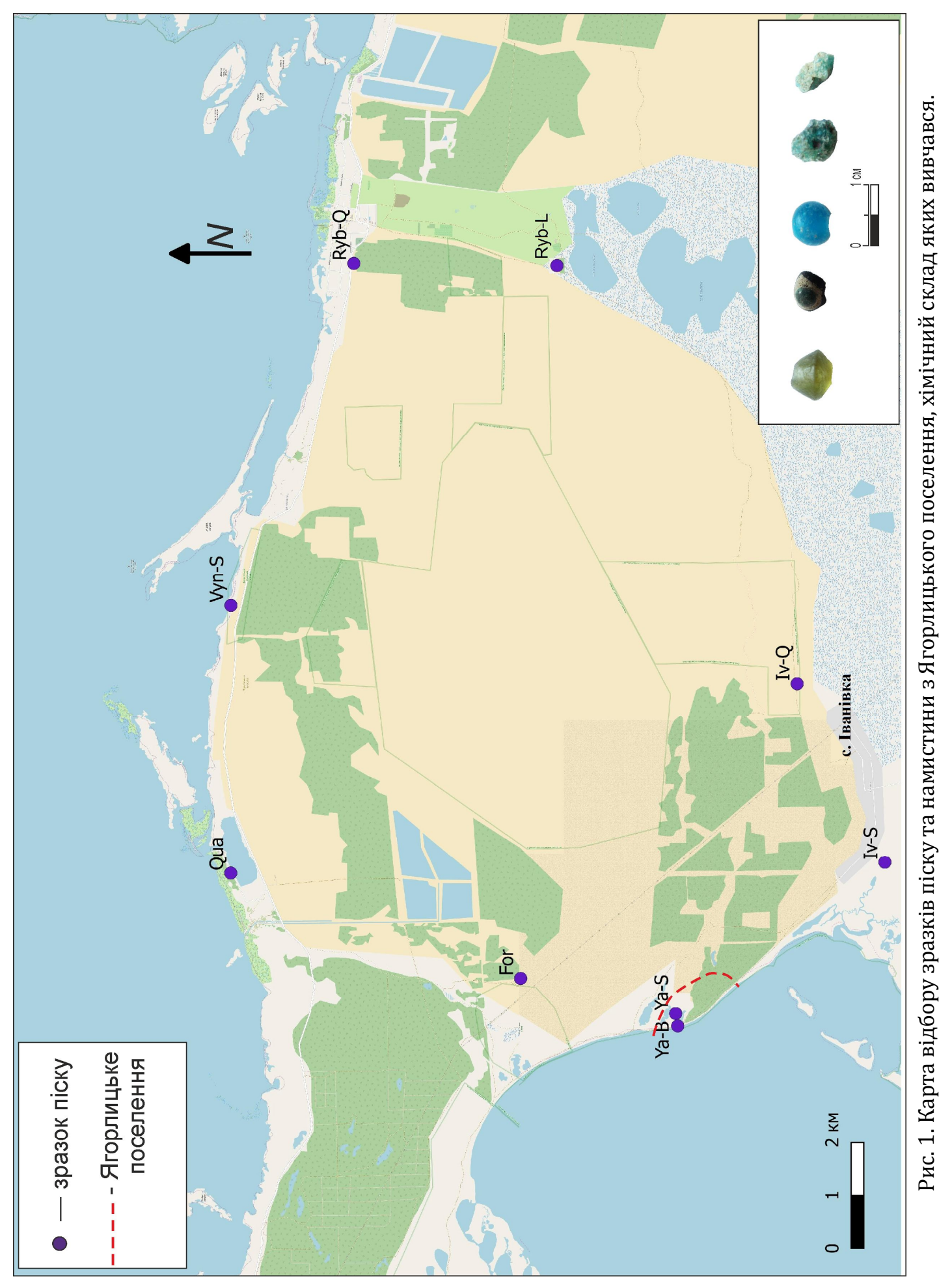






Рис. 2. Графік співвідношення $\mathrm{Al}_{2} \mathrm{O}_{3} / \mathrm{MgO}$ у зразках піску (дані 2018-2020рр.) та готових скляних намистинах (дані: Островерхов А.С. Технология античного стеклоделия...). 




Рис. 3. Графік співвідношення рідкісноземельних елементів у зразках піску, аморфних скляних шматочках і готових намистинах.

A - зразки піску, В - зразки намистин і шматочків скла; 1-5 - групи схожих графіків. 




Рис. 4. Графік співвідношення рідкісноземельних елементів у намистинах з Метоні (Піерія, Греція) та Ягорлицького поселення. 